Marquette University

e-Publications@Marquette

4-1-1997

\title{
The Fourth Biennial Meeting of the North American Fichte Society
}

Michael Vater

Marquette University, michael.vater@marquette.edu

Accepted version. Owl of Minerva, Vol. 28, No. 2 (Spring 1997): 227-232. DOI. (C) 1997 Philosophy Documentation Center. Used with permission. 


\title{
The Fourth Biennial Meeting of the North American Fichte Society
}

\author{
Michael G. Vater \\ Department of Philosophy, Marquette University \\ Milwaukee, WI
}

The meeting was held at Marquette University, March 6-9, 1997. The topic was "The Later Jena Wissenschaftslehre." The meeting opened with a 'Fichtean Sampler,' loosely focused on the Wissenschaftslehre Nova Methodo lectures 0796-99). Tom Rockmore offered an account of 'deduction' in Fichte's philosophy, noting that Fichte holds two incompatible views - a Kantian one that promises logical deduction and a weaker sense that promises only rigorous exposition of the fact of knowledge. If our interest is philosophical, not merely historical, the Kantian version is best forgotten since it puts Fichte in the unhappy position of having to make good the claims of epistemological foundationalism. A weaker but more palatable take on the Wissenschaftslehre is as a rigorous attempt to view human knowledge from the limited standpoint of the human subject. Angelica Nuzzo located the defining characteristic of the Wissenschaftslehre Nova Methodo in its abolition of the distinction, inherited from Kant, between the practical and the theoretical. The 1794 Grundlage des gesamten Wissenschaftslehre had already transmuted the distinction of practical and theoretical faculties or powers into that of real and ideal activities. The Nova Methodo lectures fashion a unified view of the activities of the 'I' and spell out a new vision of philosophic 
system, beyond the dualism of theory and practice. Kip Jensen came to much the same conclusion: the textbook version of Fichte's philosophy as an overblown version of Kant's 'primacy of the practical' is not to be found in the later Jena Wissenschaftslehre. What is found is a unitary philosophy based on the ' $I$ ' reflecting itself outside the limits of reflection. Jensen characterized the project as a drive to comprehend the incomprehensible, to cognize the very origin of reflexivity or consciousness. Jay Morris focused on freedom and selfactivity in the later Jena lectures, arguing that Fichte saw difficulties in Kant's treatment of these two themes. If Kant left Critical Philosophy without a unified account of reason, Fichte made good the lack by identifying Spontaneität and Selbsttatigkeit. Fichte thus improves Kant's philosophy by being faithful to its spirit, not its letter. HansJakob Wilhelm considered the overstated claim Fichte made to Jacobi that he could deduce the individual from the absolute ' $I$ '. Whereas Jacobi resorted to the philosophical novel to bridge the gap between theoretical construct and the living individual, in Fichte's system the individual person remains an irrational quantity that can be treated only by pragmatic means, through a politics of education. Wayne Martin closed this 'sampler' session by considering Fichte's relation to philosophy of science. One ought not simply assimilate Fichte's interest in particular sciences either to what Lauth calls Fichte's "transcendental doctrine of nature" nor to the project of Naturphilosophie. The 1794 essay "On the Concept of Wissenschaftslehre" provides an approach useful for formulating a distinctively Fichtean philosophy of science, since it treats the particular sciences not so much as bodies of theory but as distinctive cognitive practices organized around unifying theoretical principles.

The second and third sessions of the conference were devoted to influences upon Fichte and his reception by other philosophers. Daniel Breazeale offered an experimental 'fictionalist' reading of the Wissenschaftslehre as the first of a two-part attempt to avoid the standard interpretation that treats it as a piece of metaphysical dogmatism. Despite the attractiveness of such an "as-if" reading, it ignores important features of Fichte's project, e.g. its attempt to reflect real human thinking in systematic form. Claude Piche discussed Fichte's doctrine of feeling against the background of Jacobi's critique of Kant. Fichte agrees with Jacobi that neither a phenomenal object

Owl of Minerva, Vol 28, No. 2 (Spring 1997): pg. 227-232. DOI. This article is (C Philosophy Documentation Center and permission has been granted for this version to appear in e-Publications@Marquette. Philosophy Documentation Center does not grant permission for this article to be further copied/distributed or hosted elsewhere without the express permission from Philosophy Documentation Center. 
nor an object in itself can explain the origin of affection. Like Jacobi, he concludes that if no 'object' of any sort can provide the explanation, it must be sought in the knowing subject. For this reason, the Wissenschaftslehre Nova Methodo reinterprets sense-perception as 'feeling,' contrary to Kant's definition of the term. But in the end, the origin of 'feelings' remains as much a mystery as Kant's thing-in-itself. Bruce Merrill considered the Kantian origins of Fichte's thought. The "First Introduction" to the Wissenschaftslehre appropriates Kant's Third Antinomy (the conflict between freedom and determinism) and its resolution in a shift from theory to practice. It also reflects the Second Critique's 'proof' of freedom as a "fact of reason"-the site where Fichte first attached himself to Kantian philosophy in 1790. Curtis Bowman closed the second session by exploring the Kantian background to the Atheism Controversy of 1799 and Jacobi's charge that the Wissenschaftslehre was nihilistic. It was Kant's moral theology, reflected in the Attempt at a Critique of All Revelation, that moved Fichte to identify God and the moral world-order in the later Jena period. For Jacobi, this identification was too close to the position he had repudiated in the conflict over pantheism in the 1780's. Steve Hoeltzel opened the third session with a consideration of the divergences between Fichte and Schelling 1794-1797. While Fichte characterizes the system-principle or "absolute I" as free but intrinsically finite activity, Schelling insists that the absolute's freedom is incompatible with any limitation. Consequently, he claims philosophy is unable to link the finite world of human experience to its unconditioned basis-a position quite opposed to Fichte's. Dale Snow looked to later differences between the two thinkers as they emerged in the earnest but often bitter Correspondence (1799-1803). Fichte criticizes Schelling's unfortunate tendency to give a false metaphysical status to the real, while Schelling in turn laments Fichte's inability to escape the subjective and achieve true speculative insight. George Seidel connected Fichte with the tradition of innate ideas that runs through modern philosophy from Descartes to Leibniz. He argued that in Kant and Fichte, the idea takes on practical significance, signifying the "moral law written in the human heart" (Romans 2: 15). Vladimir Zeman discussed Feuerbach's relationship to Fichte. What in Feuerbach's pre-1839 idealistic period tended to be a positive assessment becomes in his mature philosophy primarily a negative critique. Michael Vater compared Fichte's phenomenalism with that of

Owl of Minerva, Vol 28, No. 2 (Spring 1997): pg. 227-232. DOI. This article is (C) Philosophy Documentation Center and permission has been granted for this version to appear in e-Publications@Marquette. Philosophy Documentation Center does not grant permission for this article to be further copied/distributed or hosted elsewhere without the express permission from Philosophy Documentation Center. 
the 2nd Century Indian Buddhist, Nagarjuna. Though both thinkers hold comparable positions on the nature of the ' $\mathrm{I}$ ', the reactive structure of perception and consciousness, and on the primitive nature of agency, the phenomenal world that Fichte presents as the horizon of actualized freedom is viewed by the Buddhist thinker as duhkha, the torrent of craving and dissatisfaction from which one seeks liberation. Lon Nease treated the "severity of the moral law" in Fichte as yet another example of Fichte's drawing the full consequences of a Kantian theory more consistently and more rigorously than Kant himself did. For Fichte no acts are morally neutral.

The fourth session was devoted to Fichte's ethics. Yolanda Estes considered the relation between pure will and intellectual intuition in the later Jena period. The moral situation of an empirical individual faced by a summons (Aufforderung) provides the material from which the philosopher abstracts the concept of intellectual intuition or pure willing that grounds the Wissenschaftslehre. This pure will has different functions in different parts of the system. In transcendental philosophy it serves as a scientific hypothesis for the construction of a theory of consciousness. As a hypothetical imperative facing a determined empirical individual, it becomes a hypothesis for theory of law (Rechtslehre). Intuited by the moral subject, it is the categorical imperative, the basis for moral theory (Sittenlehre). Alain Perrinjaquet focused on a similar theme, the way conscience functions as 'real' intellectual intuition in the Nova Methodo lectures. He illustrated the connection of conscience to intellectual intuition qua Tathandlung, and the relationship of both forms of intellectual intuition to the philosopher's consciousness. Arnold Farr considered Fichte's reformulation of Kant's categorical imperative in the later Jena writings. Kant's view of the imperative as merely the announcement of moral duty is inadequate since it does not provide for the unity of theoretical and practical reason. In Fichte's view, not only does the 'I' become conscious of its duty through the imperative, it also becomes conscious of the conditions for acting dutifully it becomes conscious of the limitations against which it must strive. The 'I' finds itself simultaneously active and passive, and this points to the equiprimordiality of the theoretical reason (the feeling of necessity) and its practical aspect (the feeling of freedom). Ken Foldes considered 
the notion of freedom found in Fichte's Orundlage des Naturrechts and elaborated Hegel's early critique of this concept.

A fifth session was devoted to the Wissenschaftslehre Nova Methodo and comparisons to earlier and later works that expounded the Wissenschaftslehre. C. Jeffrey Kinlaw explored the relation between feeling (Gefühl) and drive or disposition (Trieb) in Fichte's theory of knowledge. Since knowing an object requires that feeling be brought to consciousness, and such knowing is guided by drives-e.g. the drive to represent or, more basically, the drive to reflect-this epistemological function sheds new light on the primacy of practical reason in Fichte's philosophy. Perhaps that primacy may be more radical than has usually been acknowledged. Janet Roccanova explored the early chapters of the Nova Methodo lectures, using phenomenological concepts such as 'the given' and 'intentionality' to illustrate how Fichte guides his students through the performance of the series of acts that are under discussion. Fichte believes that one who wishes to become a philosopher must actually perform the philosophy, especially the crucial initial acts of Wissenschaftslehre that make the transition between ordinary and philosophical consciousness. In these acts are developed the germs of Fichte's notions of selfpositing, intellectual intuition, the concept of the 'I,' reason, and the opposition between concept and intuition. Gunter Zoller discussed the status of the individual in a wide range of writings from the later Jena Wissenschaftslehre, stressing the systematic place of individuality between the absolute 'I' on the one hand and the inter personality of the social and moral spheres on the other. He noted, as had Estes and Perrinjaquet, the different status accorded to individuality in the foundational part of the system, the transcendental history of consciousness, and in the Foundation of Natural Law (1796-97) and the System of Ethics (1798). Johannes Brachtendorf examined the methodological differences between the 1794/95 Grundlage and the Nova Methodo lectures of 1796-99. The earlier work invoked the notion of an apparently external' check' to account for the determinacy of the'!, encountered in representation. While this did account for externality, it fell short of Fichte's own concept of a theory of principles that fulfill the requirements of a homogeneous, idealist philosophy. The second Jena Wissenschaftslehre fulfills that requirement, since its whole account of the construction of consciousness is based on the

Owl of Minerva, Vol 28, No. 2 (Spring 1997): pg. 227-232. DOI. This article is (C) Philosophy Documentation Center and permission has been granted for this version to appear in e-Publications@Marquette. Philosophy Documentation Center does not grant permission for this article to be further copied/distributed or hosted elsewhere without the express permission from Philosophy Documentation Center. 
idea of a free and spontaneous act of self-determination by the 'I.' rves Radrizzani argued that the Vocation of Man does not represent a break with earlier Jena writings, but is fully consistent with them.

The final session was devoted to the topic of intersubjectivity and the Grundlage des Naturrechts. Speaking directly to that topic, Klaus Brinkmann emphasized the originality of Fichte as the first to argue that personal identity is socially constructed. But he noted also that the community remains a community of individuals; Fichte is not a totalitarian. Robert Williams considered the ambiguity of Fichte's philosophy of right. Fichte introduces the concept of recognition ( $A n$ erkennung) to provide a grounding both for Kant's sense of freedom and for Rousseau's social contract. Freedom and right as the existence of freedom in the world are intersubjectively mediated through recognition. But Fichte fails to fully ground his concept of right in recognition and allows it to be displaced by coercion in his analysis of security, changing community from a condition of freedom to an instrument of surveillance. Hegel is aware of this tension in Fichte and responds by consistently developing the idea of right from the concept of recognition. Jean-Christoph Merle located Fichte's Rechts/ehre in the contemporary \{late 18th Century\} debates about natural law in opposition to positive law, the criminal code. Fichte's theory of criminal law "out-Kant's Kant." Scott Scribner noted that the idea of subtle matter that Fichte uses in the 1813 Notebook on Animal Magnetism (where it signifies the medium for hypnotic communication) dates back to the 1796 Grundlage des Naturrechts. The problem of the influence of the other, overtly captured in the concept of recognition, is paralleled in this work by a generalized problem of 'influence,' represented by the notion of subtle matter. Fichte moves toward according to the unconscious an important role in social life, even at this early date. Paul Franks argued that the new method of the later Jena Wissenschaftslehre signifies a transformation in Fichte's thinking that dates back to the summer of 1795, to his first inklings that the problem of other minds and the problem of human rights might have the same solution. In the systematically worked 232 The Ow/ of Minerva 28:2 (Spring 1997) out version of the unified solution, it is the summons (Aufforderung) that testifies to the reality of other minds and provides the unified treatment of theory and practice. But the reason why Fichte may have come to the thought of the unified

Owl of Minerva, Vol 28, No. 2 (Spring 1997): pg. 227-232. DOI. This article is (C Philosophy Documentation Center and permission has been granted for this version to appear in e-Publications@Marquette. Philosophy Documentation Center does not grant permission for this article to be further copied/distributed or hosted elsewhere without the express permission from Philosophy Documentation Center. 
NOT THE PUBLISHED VERSION; this is the author's final, peer-reviewed manuscript. The published version may be accessed by following the link in the citation at the bottom of the page.

solution to human rights and other minds may have been a conviction, formed in debate with Schmid and Reinhold in 1795, that in this way heteronomy could be acknowledged as a mode of human freedom. Whether this was Fichte's actual path of thought or not, it is a philosophically interesting point of intersection between epistemological concerns about the status of other minds and concerns about normativity in practical philosophy.

Owl of Minerva, Vol 28, No. 2 (Spring 1997): pg. 227-232. DOI. This article is (C Philosophy Documentation Center and permission has been granted for this version to appear in e-Publications@Marquette. Philosophy Documentation Center does not grant permission for this article to be further copied/distributed or hosted elsewhere without the express permission from Philosophy Documentation Center. 